\title{
SOSIOLOGI SASTRA ALAN SWINGEWOOD SEBUAH TEORI
}

\author{
Tri Wahyudi \\ Pascasarjana Ilmu Sastra Fakultas Ilmu Budaya UGM \\ Jln. Sosiohumaniora, Bulaksumur, Yogyakarta \\ Email: yudicilik.30@gmail.com
}

\begin{abstract}
Abstrak
Tulisan ini merupakan pembacaan terhadap buku The Sociology of Literature yang ditulis oleh Alan Swingewood dan sejarah singkat pemikiran-pemikiran yang mempengaruhinya. Pandangan bahwa karya sastra adalah dokumen sosiobudaya diformulasikan oleh Swingewood ke dalam suatu kerangka pemikiran yang dapat dipahami secara runut dan terperinci.
\end{abstract}

Kata kunci: Swingewood, karya sastra, sosiologi sastra.

\begin{abstract}
This writing is a reading of the book. The Sociology of Literature, written by Alan Swingewood and a brief bistory of influenced ideas. The view that literature is a sociocultural document formulated by Swingewood into an understood and detailed framework.
\end{abstract}

Keywords: Swingewood, literature, sociology of literature.

\section{Pendahuluan}

Secara umum sosiologi dapat dikatakan sebagai telaah obyektif tentang manusia dan masyarakat yang mencakup proses-proses sosial yang ada di dalamnya. Disiplin ini tentu saja menempatkan segala fenomena sosial sebagai bahan kajian yang harus diurai secara ilmiah, meliputi; pola kebudayaan, ekonomi, bahasa, sastra, dan lain-lain. Dari proses ini maka akan dapat diketahui bagaimana suatu individu dapat berinteraksi terhadap komunitasnya serta mekanisme sosialnya sehingga ia dapat diterima dalam suatu perlikau tertentu. Sehingga, sosiologi secara ringkas dapat dipahami sebagai disiplin yang bertujuan untuk mengkaji perilaku manusia, pembentukan satu struktur sosial dan kesepakatan bersama dalam ekonomi, politik, budaya, dan lain-lainnya (Durkheim, 1958: 24)

Sedemikian halnya dengan sosiologi, karya sastra dianggap sebagai sebuah usaha untuk menciptakan kembali hubungan manusia dengan kekeluargaan, masyarakat, politik, agama, dan lain-lain, karena memungkinkannya untuk menjadi satu alternatif aspek estetis untuk menyesuaikan diri serta melakukan perubahan dalam suatu masyarakat (Swingewood, 1972:
12). Lebih lanjut Damono mengatakan bahwa genre sastra, khususnya novel dapat mengetengahkan satu persoalan yang turut dibicarakan oleh sosiologi yaitu masyarakat dan segala aktivitas di sekitar mereka (Damono, 1979: 68).

Persamaan ini kemudian disikapi oleh sekelompok pemikir untuk meletakkan sastra sebagai sesuatu yang terpisah dari sosiologi mengingat sastra dapat berdiri sendiri sebagai sebuah kajian yang dapat didekati melalui elemen-elemen yang ada di dalamnya. Bahkan, sebagai seni karya sastra dianggap melampaui sekedar deskripsi dan analisis ilmiah obyektif, menembus permukaan sosial, dan menjelaskan perasaan manusia terhadap apa yang telah dialaminya (Swingewood, 1972: 12). Hal ini semakin mengukuhkan bahwa karya sastra mampu merangkum sekian peristiwa yang dapat dijelaskan dengan sistematis dan terperinci melalui metode sosiologi, yang kemudian disebut sebagai sosiologi sastra.

Dalam kedudukannya sebagai susuatu yang berdialog dengan dunia di luar dirinya, karya sastra dianggap sebagai sosiokritik sastra. Dengan pelbagai sudut pandang, bermunculan 


\section{Jurnal Poetika Vol. 1 No. 1, Juli 2013}

tokoh tokoh sisologi sastra, di antaranya George Lukacs, Louis De Bonald, Madame de Stael, Robert Escarpit, Taine, Diana Laurenson dan Alan Swingewood.

Sebelum kemunculan tokoh-tokoh tersebut, Karl Marx dan Frederick Engels mengulas kehidupan manusia dari basis material. Communist Manifesto (1820) adalah buku yang menjabarkan tentang sejarah manusia dan perjuangan kelas yang diawali dari terjadinya pembagian kelas masyarakat karena perbedaan kapital. Kapitalisme dianggap sebagai faktor utama yang menyebabkan terjadinya perburuhan dan perbudakan antara kelas pemodal dan proletar. Dalam revolusi alat produksi, yang mana menghancurkan relasi sosial feodal statis dan stagnasi sistem produksi, kapitalisme mencerminkan suatu formasi sosial progresif. Pada kasus ini kapitalisme berkebalikan dengan karya sastra; sementara kapitalisme menciptakan kelas dan konflik kelas, keberadaan karya sastra justru melampaui keberadaan kelas, agama, negara, dan mampu berdialog dengan manusia di mana saja.

Melalui kritiknya terhadap karya Shakespeare, Timon of Athens, Marx mengatakan naskah tersebut adalah refleksi uang dalam fungsi sosial dalam kehidupan yang mampu mengontrol manusia, esensi sosial, dan karakter sosial. Pada diskusi lain, Marx mengatakan bahwa uang bukan hanya mengontrol manusia, namun mengalienasi menjadi 'sosok terasing' yang memisahkan dari dirinya sendiri dan sosial, yang seolah mencerminkan 'alienated ability of mankind'. Hal ini menunjukkan bahwa, menurut Marx, konsepsi sastra agak deterministik; ekonomi memaksa struktur ide dalam masyarakat dan menyatu dalam satu ideologi yang merefleksikan 'kesalahan' kesadaran kelas sosial. Sehingga dalam buku The German Ideology (1846), dikatakan bahwa hubungan antara karya sastra dan struktur ekonomi sosial adalah; 'art as ideology has no autonomy'.

Lunacharsky, Menteri Kebudayaan Soviet pada masa Lenin, mengatakan bahwa kritik Marxist menyediakan gambaran utuh perkembangan sosial suatu jaman, di mana karya sastra selalu merefleksikan kesadaran dan ketidaksadaran psikologi kelas yang diekspresikan melalui pengarang. Hal ini menunjukkan bahwa karya sastra mampu menampilkan kenyataan yang tersembunyi dan selanjutnya menjadi ilustrasi adanya kajian sastra dan masyarakat yang oleh kritikus kekinian diistilahkan sebagai 'dogmatic theory of social criticism'.

Dalam pandangan ini karya sastra seolaholah diposisikan sebagai cerminan langsung dari pelbagai struktur sosial, hubungan kekeluargaan, konflik kelas, budaya, dan lain-lain. Alan Swingewood, sebagai tokoh yang muncul pasca era Marx dan Engels berpendapat bahwa karya sastra merupakan penghubung karakter imajiner dalam sebuah novel terhadap suatu keadaan yang diciptakan oleh pengarangnya berdasarkan asal penciptaannya. Senada dengan Swingewood, Lowhental mengatakan bahwa karya sastra merupakan persoalan masyarakat yang ditulis untuk kemudian dibaca oleh masyarakat. Hal ini disebabkan oleh terjadinya gerakan-gerakan yang mendorong kemunculan karya sastra, proses penerimaan karya sastra dalam masyarakat, dan pola budaya yang dipilih agar mempengaruhi minat masyarakat untuk membaca karya sastra tersebut (Swingewood, 1972: 43).

Taine, dalam Swingewood, juga membicarakan tentang posisi karya sastra melalui tiga konsepnya; race, moment, dan milieu. Taine berpendapat bahwa karya sastra berkaitan erat dengan sikap bawaan, intelektualitas dan semangat jama, serta kondisi cuaca dan geografi karya sastra diciptakan. Interaksi ketiga hal ini melahirkan 'struktur mental', dan menjelaskan perkembangan 'germinal ideas' (awal mula ide) suatu abad atau era tertentu yang terekspresikan dalam seni atau sastra agung (Swingewood, 1972: 30).

Swingewood berpendapat bahwa, pada tahapan dasar, sosiologi dan karya sastra mengemukakan ikhtisar yang sama. Sosiologi adalah studi obyektif manusia dalam masyarakat, institusi, dan proses sosial yang dilakukan untuk mengetahui keberadaan dan pola kerjanya. 
Karya sastra, seperti halnya sosiologi, juga membicarakan tentang kehidupan manusia, cara beradaptasi, dan keinginannya untuk berubah. Akan tetapi, sebagai produk estetis, karya sastra tidak dapat dimaknai an sich sebagai fakta sosiologis semata. Karya sastra melampaui sekedar deskripsi analisis ilmiah obyektif. Ia mampu menembus permukaan sosial, bahkan menunjukkan pengalaman hidup individu diekspresikan di suatu kelompok.

Kajian sosiologi abad ke-19 dan ke20 ,yang diantaranya dilakukan oleh Comte, Spencer, Durkheim, dan Weber mulai bergulir pada persinggungan intrinsik karya sastra dengan ekstrinsiknya. Meskipun hal tersebut masih dikatakan banal, dangkal, diragukan, dan kurang berwawasan sosiologis sebagaimana yang dikemukakan oleh Swingewood;

"it is also unfortunate that a small acount of knowledge and research which does exist on the whole exceedingly dubious in quality, lacking in scientifict rigour, banal in quality of its sociological 'insights', and frequently consisting of the crudest correlations between literary text and social history" (Swingewood, 1992: 18).

Berkaitan dengan sastra dan masyarakat, Swingewood menyajikan tiga konsep dalam pendekatan karya sastranya, yaitu; sastra sebagai refleksi/cerminan jaman, sasstra dilihat dari proses produksi kepengarangannya, dan sastra dalam hubungannya dengan kesejarahan.

\section{Karya sebagai Refleksi Sosial}

Karya sastra menurut Swingewood adalah dokumen sosiobudaya yang dapat digunakan untuk melihat suatu fenomena dalam masyarakat pada masa tersebut. Inilah yang kemudian diistilahkan sebagai dokumentasi sastra yang merujuk pada cerminan jaman. Swingewood mengutip pernyataan Luis De Bonald yang beranggapan bahwa dengan melakukan close reading terhadap suatu karya sastra 'nasional', akan diketahui pula apa yang berlaku pada masyarakat tersebut. Demikian juga pernyataan Stendhal bahwa novel adalah "mirror journeying down the high road (Swingewood, 1972: 13). Lebih jauh, Swingewood menempatkan karya sastra sebagai refleksi langsung (cerminan) berbagai aspek struktur sosial, hubungan kekeluargaan, konflik kelas, trend lain yang mungkin muncul, dan komposisi populasi.

Selanjutnya, karya sastra diposisikan sebagai sentral diskusi yang menitikberatkan pada pembahasan intrinsik teks dengan menghubungkannya terhadap fenomena yang terjadi pada saat karya tersebut diciptakan. Mengutip Lowenthal, Literature and The Image of Man (1957), Swingewood menjelaskan bahwa menghubungkan pengalaman tokoh imajiner dengan sejarah, tema, dan gaya adalah cara yang paling relevan untuk mengetahui keterkaitan karya sastra dengan pola-pola kemasyarakatan yang terletak di luar teks;

"it is the task of sociologist of literature to relate the experience of the writer's imaginary characters and situations to the historical climate from which they derive. He has to transform the private equation of theme and stylistic means into social equations" (Swingewood, 1972: 14).

Transformasi dari pemaknaan kedirian sastra menuju pemaknaan sosiologispendekatan esktrinsik, menuai beberapa kritik, diantaranya; metode ini semata-mata menjadikan karya sastra sebagai sumber penggalian informasi sosiologis, dan bahwa karya sastra dipindahkan dari luar dirinya karena kurangnya aparatus kritik untuk memahami dan mengevaluasi. Metode ini juga dianggap 'berbahaya' untuk diterapkan ketika seorang sosiolog (peneliti) tidak memiliki kemampuan cukup yang cukup untuk mengurai partikular historisnya. Oleh karenanya, hanya seorang orang yang memiliki pengetahuan cukup tentang struktur sosial dari sumber lain di luar karya sastra lah yang mampu menemukan, bagaimana dan sejauh mana tipe sosial dan perilaku tertentu direproduksi ke dalam sebuah novel baik memadai maupun tidak.

Dengan memahami bahwa karya sastra adalah hasil kreasi bebas, tidak menutup kemungkinan muncul karya sastra yang 


\section{Jurnal Poetika Vol. 1 No. 1, Juli 2013}

'mengingkari' semangat jamannya, atau setidaknya berbeda dari apa yang sedang berlangsung secara khusus pada masa tersebut. Sehingga, permasalahan sebenarnya adalah apa yang akan terjadi apabila ada karya sastra -yang dianggap sebagai cerminan jaman -tidak 'setia', dan atau tidak menggambarkan kebenaran historis seperti yang telah diasumsikan? Sejauh mana karakter fiktif dan tipikal situasi mewakili suatu sejarah tertentu?

Untuk menjawab persoalan tersebut, konsep refleksi/cermin harus mengabaikan proses produksi dan kepengarangannya. Para pengarang besar, menurut Swingewood, tidak menyederhanakan semesta sosial ke dalam terma deskripsi yang luas, melainkan lebih pada tugasnya untuk melakukan kritik dan menciptakan 'takdirnya' sendiri dalam menemukan makna dan nilai sosial. Masyarakat dapat diibaratkan sebagai ensemble institusi sosial yang mengontruksi suatu struktur sosial, meliputi; norma, standar tingkah laku agar seseorang dapat diterima oleh orang lain, dan nilai yang secara sadar diformulasikan dan disadari untuk dipatuhi secara sosial. Karya sastra berfungsi merefleksikan konstruksi tersebut melalui intrinsik imajinernya, misalkan merefleksikan dan memperkuat serta nilai-nilai material sosiologis.

Menyinggung karya Balzac dan Gissing yang mengusung tema devaluasi nilai pada abad ke-19, Swingewood mengatakan bahwa arti 'kebenaran' dari sastra agung dan kelompok sosial bersandar pada 'nilai-nilai otentik' kemanusiaan, yaitu; kebutuhan, aspirasi, dan hasrat yang termediasi melalui interaksi sosial. Sehingga, tugas seorang sosiolog bukan sekedar menemukan refleksi sosial dan historis karya sastra, melainkan juga mengartikulasikan nilainilai yang yang tertanam di dalamnya, yang oleh Raymond William disebut dengan structure of feelings.

Lowenthal, setelah melakukan penelitian terhadap hero Cervantes-Don Quixote, mengatakan bahwa sosiologi sastra seyogyanya menemukan core of meaning dari karya sastra yang berbeda-beda dan berisi berbagai aspek pemikiran dan perasaan yang terekspresikan melalui kelas sosial, pekerjaan, cinta, alam, dan seni. Lowenthal menyimpulkan bahwa pemaknaan sosial kedirian tokoh berhubungan dengan masalah perubahan sosial. Dengan demikian, karya sastra sebagai refleksi nilai dan perasaan, menunjukkan derajat perubahan masyarakat dan respon mereka terhadap pengalaman tersebut;

"Thus literature, as reflection of values and feeling, points both to the degree of change occuring in different societies as well as to the manner in which individuals become socialized into the social structure and their response to this experience" (Swingewood, 1986: 16).

Akan tetapi, Swingewood mengkritik pernyataan tersebut dengan mengatakan bahwa seiring berkembangnya kompleklsitas perubahan dan struktur sosial, akan sangat sulit untuk meneliti karya sastra sebagai cerminan langsung dari suatu keadaan. Pada abad ke-18, mungkin masih ada peluang untuk menganalisis karya Filding, Tom Johns, sebagai sebuah potret sosial suatu masyarakat. Namun, sejalan dengan dimulainya era industrialisasi dan berkembangnya suatu komplesitas trsuktur sosial yang meliputi keberagaman kelas dan status sosial, bersamaan dengan maraknya budaya massa, tidak menutup kemungkinan karya sastra tidak menutup kemungkinan karya sastra sebagai hasil ciptaan manusia dipengaruhi oleh kep[entingan-kepentingan tersebut.

\section{Kepengarangan dan Produksi}

Pendekatan ini oleh Swingewood dipindahkan dari pembahasan karya sastra ke pembahasan situasi produksi karya sastra, khususnya situasi sosial pengarang. Robert Escarpit (Sociology de la Litterature, 1958), yang lebih dahulu mencermati kajian ini, mengatakan bahwa patronase dan biaya produksi memiliki signifikansiyang sama dengan teks sastra sebagai. Menurut penelusurannya, pada era aristokrasi abad ke-18, hubungan antara pengarang dengan patronnya sering terlihat 'miring dan 
menjijikkan'. Kebangkitan penerbitan murah dan produksi massa telah menggeser kedudukan para penulis dari kemerdekaannya menjadi sebuah profesi. Tahapan demokratisasi budaya -istilah Karl Mannheim (sosiolog Jerman), sangat signifikan bagi kemunculan novel dan genre kelas menengah yang kemudian dibayangbayangi oleh budaya massa dan komersialisasi sastra.

Perbincangan utama kemudian cenderung pada meningkatnya gejala alienasi pengarang dari masyarakat diikuti oleh konsekuensinya terhadap karya sastra dan isinya. Fragmentasi sosial ini seringkali dihubungkan dengan runtuhnya patronase di akhir abad ke-18 dan tampilnya pengarang sebagai anggota dari 'free floating intelegentsia". Pada masyarakat pra-industri dikatakan bahwa harmoni antara pengarang dan pembaca sangat dipentingkan, misalkan dalam; Periclean Athens, Aescyblus, Sopochles, dan Euripidis, yang kurang lebih berintegrasi dengan masyarakat dan tidak menempatkannya sebagai kelas yang terpisah.

Setelah memasuki era industri, fenomena pasar yang memudahkan pengarang mendapatkan royalti kemudian melemahkan tematik sastra yang sebelumnya menjadi bahan penilaian suatu karya. Masih dibayangi oleh budaya massa, selera pasar dan permainan kapital menciptakan keberjarakan dan alienasi antara konten sastra dengan gejala yang ada di masyarakat;

"but with the rise of a specially middleclass reading public, lending libraries, and cheap publishing, writers were forced more and more to depend on the system of royalties for their living: literary, as already observed, turned into a trade."

"a persistent theme of this particular sociological approach is the emphasize on the increasing alienation of the writer from his society and the consequent impact on literary style and content" (Swingewood,1972: 18).

Pada akhir abad ke-18 dan awal abad ke19, para pengarang yang memiliki kreativitas benar-benar mengalienasi diri dari masyarakat dan memperkuat dirinya dengan menciptakan kelompok-kelompok intelektual. Titik awal yang menyebabkan keterpisahan ini adalah masa ketika pengarang masih memungkinkan untuk mengidentifikasi masyarakat kelas menengah dan mengekspresikan nilai-nilainya melalui karya sastra, yang sosial dan rasional, dari masa ketidakpastian dan keragu-raguan yang didasarkan pada psikologis dan subyektivitas. Tahun ini sering dicatat sebagai tahun revolusi (1948), ketika Eropa sedang mengalami ketegangan konflik. Setelah peristiwa ini, hampir sebagian besar kelas menengah di negara Eropa Barat mengalami pencapaian kekuatan politisnya.

Dua orientasi berbeda tentang studi sosiologis sastra yang saling bertentangan ini cenderung memisahkan tujuan penelitian, yaitu pada konteks sosial penulisan atau teks sastra dan pemaknaan sosialnya. Para sosiolog yang penelitiannya berangkat dari teks sering beranggapan bahwa adanya prasyarat sosial dalam menulis tidak relevan untuk sosiologi sastra. Lucien Goldmann berpendapat bahwa bagi para penulis besar, kondisi sosial saat proses penciptaan dapat diatasi dan dilampaui, sehingga makna yang terdapat dalam teks tidak ada hubungannya dengan kondisi pasar kepengarangan. Ia menunjukkan bahwa penulis tingkat kedua adalah mereka yang gagal membebaskan diri dari konteks sosial-ekonomi, sehingga hal tersebut terbawa ke dalam karya, mendominasi struktur dan isinya murni sangat temporal. Goldmann juga menegaskan bahwa pada abad ke-18 dan ke-19 pengarang menciptakan karya untuk pembaca khusus, menciptakan tokoh dan peristiwa yang sesuai dengan nilai-nilainya, terutama keterkaitan karya terhadap jenis kelamin pembacanya. Baik karya Dickens maupun Balzac, struktur novel mereka bergantung pada kebutuhan publikasi serial, dan elemen aneh pada drama karya Balzac (tokoh kriminal, peleraian dan kekerasan yang tiba-tiba) jelas berhubungan dengan penerbitan majalah Perancis pada tahun 1930an dan 1940-an. Pengarang besar, lanjutnya, tidak menulis dalam bentuk serial. Yang lebih signifikan adalah bahwa saat ini sangat sulit 
untuk menghubungkan antara pembaca, penerbit, hubungan kelompok sosial dengan sastra agung melalui cara pemaknaan apapun.

\section{Sejarah dan Karya Sastra}

Swingewood mengawali pembahasannya dengan pentingnya keterampilan dan usaha keras untuk melacak bagaimana kerja sastra dapat diterima oleh masyarakat tertentu pada peristiwa sejarah tertentu. Berikutnya ia mengilustrasikan perjalanan kesastraan Guy de Mappasant hingga diterima di Inggris pada tahun 1980-an dan 1990-an, dengan efek transisi yang dibumbui seksualitas dan kenaifan sebagai satu bentuk modernitas kekaryaan. Seksualitas dalam novel Thomas Hardy dan George Mcore dipandang lebih terbuka dibandingkan dengan karya Dickens dan Eliot. Hal ini kemudian dianggap mengilustrasikan konflik nilai antara praktisi sastra tradisional dengan 'inovator' pada akhir era Inggris Victoria. Melengkapi penjelasannya, Swingewood mengungkapkan fakta Lowenthal yang membeberkan keberhasilan Doestoevsky (1880-1920) mengasimilasi kelas atas dan kelas menengah Jerman ke dalam ideologi 'aneh'. Menurut Lowenthal, tema yang mendominasi kesastraan Jerman adalah irasionalitas Doestoevsky yang berkembang ke arah bisnis dan masyarakat kapitalistik. Apabila ekonomi dan struktur politik telah diterima oleh masyarakat, maka kompetisi ideal antarmanusia, melalui berkembangnya pemikiran dan kemauan, harus digantikan dengan pemujaan terhadap ideologi non-rasional yang keluar dari forum verifikasi kritik. Bagi para kritikus Jerman, Dostoevsky dianggap sebagai anti-intelektual, mistis, dunia yang lain, dan berlawanan dengan ide sosialisme, di mana novelnya digunakan untuk melawan usaha 'reorganize society' yang diagungkan oleh para sosialis Jerman. Gejala ini, menurut Lowenthal, menunjukkan adanya krisis kesadaran yang melanda Jerman selama 40 tahun dan berujung pada irasionalisme ekstrim, anti-intelektualisme, dan anti-sosialisme Nazi.

Lowenthal menyimpulkan bahwa para seniman memotret realitas lebih dari realitas itu sendiri. Sedangkan menurut Richard Hoggart, Literature and Society (1966), sastra agung menembus lebih dalam pengalaman manusia karena kapasitas sastra itu tidak hanya melihat pergerakan individu, akan tetapi jauh lebih dalam melihat gerakan-gerakan di bawah yang tertampak. Dan sastra juga mampu menyatukan ketidaksamaan pola sebuah masyarakat ibarat menempatkan magnet di antara serpihan besi.

Dari abstraksi di atas, Swingewood menyatakan bahwa pengarang dan kekaryaannya memiliki implikasi yang dalam terhadap manusia dan kondisi sosialnya;

"it is interesting to note that on this point most sociologists of literature and literary critics are agreed: one studies great writers and their text precisely because their greatness implies deep insight into buman and the social condition" (Swingewood, 1972: 22).

Pada bahasan terakhirnya Swingewood menyinggung kriteria tentang 'greatness' yang diselesaikan dengan great literature survives, serta tujuan dasar sosiologi yang dimaksudkan untuk memahami ciri-ciri kerja masyarakat secara keseluruhan dan posisi manusia dalam masyarakat. Pernyataan tersebut ditegaskannya dengan meminjam pendapat Lowenthal bahwa karya sastra mencakup nilai dan simbol fundamental yang menyediakan kohesi kelompok-kelompok yang berbeda.

\section{Sosiologi Sastra Alan Swingewood dalam Studi Sastra}

Pada dasarnya karya sastra merupakan ilmu yang menenempatkan karya sastra terhadap aspek-aspek di luar dirinya, yakni masyarakat. Hal ini tentu saja akan memberikan kontribusi yang besar terntang fungsi-fungsi sastra sebagai produk masyarakat sekaligus menemukan manfaatnya terhadap struktur sosial yang menghasilkannya.

Tepatan keilmuan sosiologi sastra yang memindahkannya dari wilayah otonom kekaryaan sangat relevan mengingat karya sastra tidak lahir dari kekosongan budaya. Karya sastra dapat dikatakan sebagai 
representasi suatu kebudayaan tertentu. Merunut pada yang telah diungkapkan di atas, Swingewood memiliki 'koleksi' pendapat yang lengkap bahwa karya sastra buklanlah artefak, melainkan hasil proses dialektika pemikiran. Sehingga, pengarang memiliki ruang yang luas untuk memainkan kepekaannya terhadap perasaan dan pengalamannya melalui karyakaryanya. Hanya saja, karya sastra dlam teori ini bukan semata-mata cerminan langsung realitas masyarakat secara keseluruhan. Dalam artian, pengarang sah-sah saja memberikan sentuhan yang sama sekali berbeda dengan catatan masih berdasarkan kebenaran.

Dengan tiga konsep sosiologi sastra Swingewood, seorang peneliti sastra dapat memetakan fenomena masyarakat dalam linearitas genetisnya sekaligus menemukan keberpihakan karya sastra tersebut. Ketiga konsep ini juga sangat mungkin digunakan bersama-sama terhadap satu obyek material yang sama untuk menemukan apakah karya sastra tersebut adalah refleksi kondisi sosial suatu masyarakat ataukah sudah dipengaruhi oleh kepentingan-kepentingan yang mempengaruhi proses produksinya.

\section{Daftar Pustaka}

Swingewood, Alan. 1986. Sociological Poetics and Aesthetic Theory. London: Macmillan Press.

.1992. A Short History of Sociological Thought. London: Macmillan Press.

Swingewood, Alan and Diana Laurenson. 1972. The Sociology of Literature. Paladine.

Durkheim, Emile. 1958. The Rules of Sociological Method. Glencoe: Fress Press.

Damono, Sapardi Djoko, dan S. Effendy. 1979. Sosiologi sastra: Sebuah Pengantar Ringkas. Jakarta: Pusat Pembinaan dan Pengembangan Bahasa. 